\title{
PENYEBAB GANGGUAN AUTIS MELALUI JALUR NEUROINFLAMASI
}

\author{
Causes of Autism Disorders through Pa th Neuroinflamasi \\ Alvina Putri Purnama Sari, Mohamad Amin, Betty Lukiati \\ Pendidikan Biologi, Pascasarjana, Universitas Negeri Malang \\ Jl. Semarang No. 5 Malang, 65146, Indonesia \\ E -mail: alvinapps1@gmail.com
}

\begin{abstract}
Autism is a complex developmental disorder in children who are affected by many factors. Factors that cause autism include genetic, environmental, immune system disorders, and inflammation. Inflammation occurs because of the mediators that interfere with the work of a network resulting in a response to the mediator. One of inflammatory mediators are cytokines (IL-6 and TNF- $\alpha$ ). IL-6 and TNF- $\alpha$ with high amounts in the brain resulting in disruption or reduction in adhesion and migration of nerve cells that result in disruption of the work of the Blood Brain Barrier (BBB) that function to maintain the normality of the central nervous system homeostasis. Inflammation that occurs in brain cells or chronic neuroinflamasi already become one of the causes of autistic disorder in children.
\end{abstract}

Keywords: autism, neufoinflammation

\begin{abstract}
Abstrak-Autis merupakan gangguan perkembangan yang kompleks pada anak yang dipengaruhi oleh banyak faktor. Faktor penyebab autis diantaranya genetik, lingkungan, gangguan sistem imun, dan inflamasi. Inflamasi terjadi karena adanya mediator yang mengganggu kerja suatu jaringan sehingga menimbulkan respon terhadap mediator tersebut. Salah satu mediator inflamasi adalah sitokin (IL-6 dan TNF- $\alpha$ ). IL- 6 dan TNF- $\alpha$ dengan jumlah tinggi dalam otak mengakibatkan gangguan atau penurunan adhesi dan migrasi sel saraf yang mengakibatkan terganggunya kerja dari Blood Brain Barrier (BBB) atau sawar darah otak yang berfungsi menjaga normalitas homeostasis sistem saraf pusat. Inflamasi yang terjadi pada sel otak atau neuroinflamasi yang sudah kronis menjadi salah satu penyebab terjadinya gangguan autis pada anak.
\end{abstract}

Kata kunci: autis, neuroinflamasi

\section{PENDAHULUAN}

Perkembangan gangguan autis mengalami peningkatan selama dua dekade terakhir (WHO, 2013). Amerika Serikat adalah salah satu negara dengan jumlah penderita autis terbanyak yaitu 1:68, dengan perbandingan laki-laki dan perempuan 5:1 (CDC, 2016). Peningkatan gangguan autis juga terjadi di Asia salah satunya negara Indonesia. Tahun 2011 penderita autis di Indonesia 1:1000, lebih banyak dibandingkan sepuluh tahun sebelumnya (Kementrian Kesehatan RI, 2015).

Autis yaitu gangguan perkembangan saraf atau neurodevelopmental pada anak yang dipengaruhi banyak faktor. Faktor tersebut diantaranya genetik dan faktor lingkungan (Onore et al., 2012; Lee et al., 2016), gangguan sistem imun (Boyadjieva \& Varadinova, 2015; Careaga et al., 2010), serta inflamasi (Vargas et al., 2005; Young et al., 2016).

Inflamasi yaitu peradangan yang terjadi karena adanya mediator (Wassung, 2012; Adhimarta et al., 2015) yang mengganggu kerja suatu jaringan sehingga menimbulkan respon terhadap mediator tersebut (Repa et al., 2007). Salah satu mediator yang memicu inflamasi yaitu sitokin (Huang, 2004). Sitokin merupakan molekul protein yang memiliki peran dalam komunikasi antar sel (Coondoo, 2011) salah satunya 
yaitu patofisiologi inflamasi (Mokart et al., 2002; Halter et al., 2005). Sitokin dapat dihasilkan oleh beberapa sel seperti limfosit, sel makrofag, dan sel mast (Khan, 2008).

Sitokin yang berperan sebagai proinflamasi diantaranya TNF- $\alpha$ (Netea at al., 2003; Schmidt et al., 2005) dan IL-6 (Li et al., 2009; Perkins, 2014). Inflamasi yang terjadi pada saraf atau neuroinflamasi menjadi salah satu penyebab gangguan autis (Vargas et al., 2005; Tsilioni et al., 2015).

\section{AUTIS}

Autis merupakan gangguan yang disebabkan bukan karena faktor tunggal (CDC, 2014) melainkan banyak faktor yang terlibat sehingga disebut sebagai gangguan yang kompleks (Careaga et al., 2010). Anak yang mengalami gangguan autis kesulitan berkomunikasi dengan orang lain (Tsilioni et al., 2015), mengalami gangguan sosial dan sering melakukan sesuatu secara berulangulang (Gips \& Srinivasan, 2012). Setiap anak yang mengalami gangguan autis memiliki penyebab yang berbeda-beda.

Penyebab terjadinya autis diantaranya yaitu faktor genetik. Gen yang terlibat dalam gangguan autis ratusan jumlanya (Elamin \& Al-Ayadhi, 2015), gen tersebut menjadi penyebab autis karena mengalami mutasi (Devlin \& Scherer, 2012; Elamin \& Al-Ayadhi, 2015).

Faktor lingkungan juga berkontribusi terhadap gangguan autis (Sealey et al., 2016). Faktor tersebut diantaranya polusi udara (Volk et al., 2011), nutrisi (Schmidt et al., 2011; Schmidt et al., 2012), dan merkuri (Wijngaarden et al., 2013; Picciotto et al., 2010). Seorang ibu selama masa kehamilan pertama hingga bulan ketiga yang tidak memperhatikan asupan makanan atau nutrisi kehamilannya lebih mungkin melahirkan anak dengan gangguan autis (Schmidt et al.,
2011) karena masa kehamilan tersebut merupakan masa perkembangan janin yang sangat rentang dengan faktor luar. Contoh lain yaitu ibu yang mengandung harus berhati-hati dalam mengkonsumsi makanan, salah satunya yaitu ikan laut. Ikan laut yang kita ketahui terkadang mengandung merkuri atau logam lainnya, sehingga ketika tidak baik dalam pengolahannya dapat ikut masuk dalam darah janin. Gangguan autis diidentifikasi memiliki kandungan logam darah yang tinggi dibandingkan dengan anak normal lainnya (Picciotto et al., 2010).

Faktor lain penyebab autis adalah terjadinya gangguan sistem imun (Money et al., 1971; Enstrom et al., 2009) salah satunya adalah neuroimun (Gottfried et al., 2015). Neuroimun yang tidak normal dapat mempengaruhi kerja sistem saraf (Vargas et al., 2005) sehingga memicu terjadinya neuroinflamasi yang merupakan salah satu faktor penyebab gangguan autis.

Bayi yang lahir prematur diketahui memiliki potensi mengalami gangguan autis (Hack et al., 2009;. Indredavik et al., 2004; Hwang et al., 2013;) karena dipengaruhi oleh keterlambatan perkembangan sehingga bayi tersebut akan sering mengamali gangguan seperti alergi lingkungan, infeksi, dan stress (Angelidou et al., 2012). Faktor tersebut menjadi salah satu penyebab pengaktifan sel mast.

Sel mast merupakan bagian dari jaringan ikat multifungsi dan terutama berhubungan dengan beberapa penyakit. Proses pengaktifan sel mast akan menimbulkan suatu reaksi salah satunya yaitu degranulasi sel atau pelepasan mediator kimia dari dalam sel tersebut (Jalal, 1998). Mediator kimia yang dilepaskan oleh sel mast penting dalam proses alergi, sistem kekebalan serta respon inflamasi (Theoharides et al., 2010). Aktifasi sel mast dapat terjadi 
juga ketika adanya pengaruh lingkungan, protein pemicu dalam otak, serta gen tertentu (Theoharides et al., 2013).

\section{INFLAMAS I}

Inflamasi atau peradangan merupakan reaksi tubuh terhadap suatu infeksi, iritasi atau terjadinya luka yang dipengaruhi oleh banyak mediator (Srdan Stankov, 2012) . Inflamasi menjadi salah satu penyebab gangguan sistem tubuh lainnya karena inflamasi melibatkan selsel imun yang juga terlibat dalam sistem dalam tubuh (Gips \& Srinivasan, 2012). Inflamasi yang terjadi dalam tubuh terdiri dari dua jenis yaitu inflamasi akut dan inflamasi kronis. Inflamasi akut terjadi secara mendadak yang bertujuan untuk menanggapi sesuatu benda yang secara tiba-tiba masuk kedalam tubuh (Ashley et al., 2012). Inflamasi kronis terjadi karena perlawanan inflamasi akut yang tidak maksimal sehingga menimbulkan gangguan pada sistem tubuh yang lainnya bahkan dapat menimbulkan penyakit atau gangguan baru (Schottenfeld \& Dimmer, 2006).

Inflamasi yang terjadi pada anak dapat dideteksi sejak masa kehamilan (Knuesel et al., 2014). Autoantibodi yang dimiliki oleh ibu dapat ditransfer melalui plasenta dan air ketuban sehingga mampu meningkatkan mediator proinflamasi. Inflamasi terjadi ketika adanya mediator berupa bahan kimia yang dilepaskan dalam cairan ekstraseluler (Wassung, 2012). Sitokin merupakan salah satu mediator terjadinya inflamasi (Feghali \& Wright, 1997), diantaranya yaitu TNF $\alpha$ dan IL-6 (Netea et al., 2003; Gouwy et al., 2005).

Sitokin memodulasi fungsi otak sehingga terjadi peradangan sebagai bentuk respon dari otak. Penderita autis mengalami peningkatan kadar TNF- $\alpha$ dan IL-6 (Boyadjieva \& Varadinova, 2015) yang terjadi di darah dan di otak
(Ashwood et al., 2006; Chez et al., 2007).

Tingginya kadar sitokin di otak memicu terjadinya neuroinflamasi (Careaga et al., 2010). Neuroinflamasi yang kronis pada otak merupakan salah satu penyebab terjadinya gangguan autis (Vargas et al, 2005;. Chez et al, 2007) sehingga autis disebut dengan gangguan neurodevelopmental (Angelidou et al., 2012).

\section{$\begin{array}{lllllllll}M & \text { E } & \text { K } & \text { A } & \text { N } & \text { I } & \text { S } & \text { M } & \text { E }\end{array}$ NEUROINFLAMASI PADA GANGGUAN AUTIS}

Sel mast merupakan salah satu komponen yang berperan dalam mekanisme neuriunflamasi, beberapa sel mast terletak di perivascularly dekat dengan neuron dan mikroglia terutama di bagian hipotalamus (Tsilioni et al., 2015). Anak autis mengalami neuroinflamasi didaerah anterior dari neokorteks (Vargas et al., 2005) yang dihasilkan dari aktifnya sel mast sehingga mengeluarkan mediator dan berinteraksi dengan sel mikroglia (Anderson et al., 2008) yang memiliki fungsi penting dalam otak. Mikroglia merupakan sel mediator yang berperan penting dalam neuroinflamasi (Streit et al., 2004).

Mikroglia yang aktif merupakan salah satu bentuk respon fisiologi yang berfungsi melawan adanya benda asing atau zat lain yang masuk ke dalam otak, dalam hal ini adalah mediator inflamasi (sitokin), ketika sudah mengakibatkan respon yang kronik karena overaction dari mikroglia maka akan berujung pada gangguan neurodegeneratif salah satunya adalah autis (Wang et al., 2014)

Neuroinflamasi yang terjadi pada anak autis dapat terjadi ketika masih dalam kandungan. Autoimun, gangguan fungsional plasenta, infeksi saat kehamilan, serta lahirnya bayi secara prematur menjadi latar belakang seorang anak akan mengalami autis. Hal tersebut 
karena seorang anak tersebut dinilai lemah ketika menghadapi gangguan lingkungan, ketika mengalami alergi, sehingga dapat memicu pengaktifan sel mast yaitu agen penting yang merespon adanya inflamasi dengan mengeluarkan mediator inflamasi (IL-6, dan TNF).

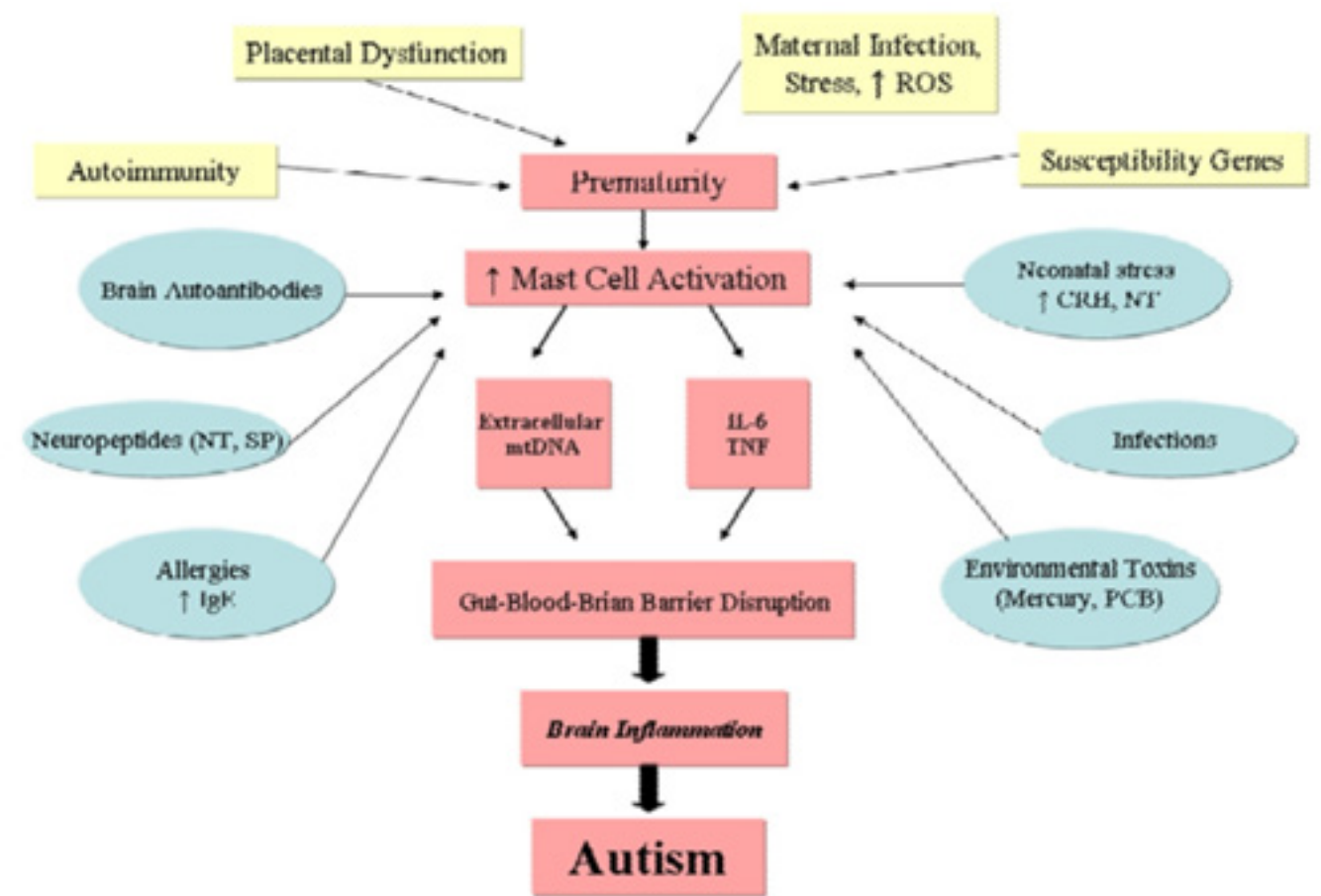

Gambar 1. Jalur Neuroinflamasi pada Autis (Angelidou et al., 2012:2).

Il-6 dan TNF- $\alpha$ merupakan glikoprotein yang keberadaanya dalam otak harus dalam jumlah yang normal atau rendah (Gadient \& Otten, 1994) tingginya sitokin ini dapat menjadi pemicu terjadinya neuroinflamasi (Chez et al., 2007).

Sitokin (IL-6 dan TNF) sebagai mediator inflamasi masuk ke dalam otak melalui mekanisme transpor aktif sehingga mengganggu kerja sistem neuroimun karena jumlahnya yang tidak seimbang dengan sel-sel kekebalan tubuh (Limfosit) (Ashwood et al., 2004).

Berdasarkan Gambar 1. dapat dijelaskan secara lanjut bahwa pemicu pengeluaran mediator (IL-6 dan TNF- $\alpha$ ) tersebut akan mengganggu kerja dari Blood Brain Barrier (BBB) atau sawar darah otak yang berfungsi menjaga normalitas homeostasis sistem saraf pusat. IL-6 dan TNF- $\alpha$ pada konsentrasi tertentu atau dalam jumlah yang tinggi akan mengurangi jumlah dendrit primer dalam otak, kelenjar, panjang dendrit, dan mempengaruhi kelangsungan hidup dan aktifitas neuron (Gilmore at al., 2004) selain itu juga dapat menyebabkan perubahan adhesi sel saraf sehingga mengakibatkan ketidakseimbangan rangsangan oleh sel saraf tersebut. IL-6 dan TNF- $\alpha$ yang meningkat pada penderita gangguan autis berada pada sel granula di cerebellum berdasarkan penelitian in vitro, sehingga menyebabkan gangguan atau penurunan adhesi dan migrasi sel tersebut. Gangguan adhesi dan migrasi sel saraf yang menjadi akibat ketidakseimbangan sinapsis rangsangan sel tersebut yang diakubatkan oleh 
peningkatan sitokin ini dapat dijadikan dasar komunikasi sel penyebab gangguan autis (Wei et al., 2011).

Gangguan yang terjadi pada bagian sel saraf otak karena adanya peningkatan sitokin (IL-6 dan TNF- $\alpha$ ) mengakibatkan fungsi BBB terganggu sehingga terjadi penghambatan sistem kerja saraf pusat sehingga menyebabkan neuroinflamasi atau radang otak (Angelidou et al., 2012). Neuroinflamasi yang kronis pada otak ini menyebabkan terjadinya gangguan autis pada anak (Vargas et al, 2005).

Gangguan autis yang disebabkan karena adanya inflamasi pada otak sudah banyak menjadi bahan penelitian. Para peneliti menitikberatkan adanya peran IL-6 dan TNF- $\alpha$ atau beberapa sitokin lain yang berkontribusi dalam patologi autis. Namun, penelitian yang dilakukan belum mampu mengungkap proses secara lebih spesifik peran sitokin tersebut dalam patogenensis autis (Wei et al., 2013). Penelitian yang dilakukan oleh Vargas et al., 2005, Li et al., 2009, Wei et al., 2011, menjelaskan kadar IL-6 dan TNF- $\alpha$ pada anak autis lebih tinggi dibandingkan dengan anak normal, dan ini sudah menjadi bukti salah sau jalur penyebab terjadinya autis (Wei et al., 2013) sehingga perlu tindak lanjut khusus untuk meneliti mekanismenya.

Penjelasakn mekanisme yang terjadi baru dapat dijelaskan secara umum seperti yang sudah dijelaskan sebelumnya. Kajian ini menjadi hal yang perlu ditindaklanjuti lebih dalam dan spesifik sehingga menjadi jelas jalur atau patologi autis yang disebabkan oleh sitokin proinflamasi yang menjadi salah satu penyebab gangguan autis. Hal tersebut karena sudah dibuktikan dengan penelitian bahwa peningkatan sitokin proinflamasi tersebut akan memberikan efek merugikan dalam jangka panjang terhadap fisiologi dan patologis di otak (Yirmiya \& Goshen, 2011).
Oleh karena itru perlu tindak lanjut yang dapat dilakukan dengan pemberian terapi baru yang mampu mempengaruhi kerja sitokin proinflamasi sehingga dapat menekan terjadinya gangguan autis (Wei et al., 2013).

\section{SIMPULAN}

Neuroinflamasi dapat menjadi salah satu penyebab terjadinya gangguan autis karena aktifnya sel mast di otak sehingga mengeluarkan mediator proinflamasi dan berinteraksi dengan sel mikroglia. Mediator tersebut berupa glikoprotein yaitu IL-6 dan TNF- $\alpha$. Tingginya mediator tersebut didalam otak menyebabkan gangguan atau penurunan adhesi dan migrasi sel saraf yang mengakibatkan terganggunya kerja dari Blood Brain Barrier (BBB) atau sawar darah otak yang berfungsi menjaga normalitas homeostasis sistem saraf pusat. Keseimbangan sistem saraf pusat yang terganggu mengakibatkan kerja seluruh sistem terutama diotak menjadi terganggu, sehingga neuroinflamasi yang kronis didalam otak menjadi salah satu patologi terjadinya gangguan autis.

\section{DAFTAR PUSTAKA}

Adhimarta, W., Islam, A.A., Maliawan, S., Lowrence, G. S., Patellongi, I. 2015. The Role Of Recombinant Il-10 On The Serum Level Of Tnf-A, One Hour Post Traumatic Brain Injury Of The Wistar Rat. Balimed, 4 (1): 24-27.

Anderson A.A., Ushakov D.S., Ferenczi M.A., Mori R., Martin P., \& Saffell J.L. 2008. Morphoregulation by Acetylcholinesterase in Fibroblasts and Astrocytes. J Cell Physiol, 215(1):82-100.

Angelidou, A., Asadi, S., Alysandratos, K. D., Karagkouni, A., Stella K., \& Theoharides, T. C. 2012. Perinatal 
Stress, Brain Inflammation and Risk of Autism Review and Proposal. BMC Pediatrics, 12:89.

Ashwood P., Anthony A., Torrente F., Wakefield A.J. 2004. Spontaneous Mucosal Lymphocyte Cytokine Profiles in Children with Autism and Gastrointestinal Symptoms: Mucosal Immune Activation and Reduced Counter Regulatory Interleukin. J Clin Immunol, 10:664673.

Ashwood P., Wills S., Van de Water J. 2006. The Immune Response in Autism: a New Frontier for Autism Research. J Leukoc Biol, 80:1-15.

Boyadjieva, N., \& Varadinova, M. 2015. Role of Fetal Alcohol Exposure on Molecular and Epigenetic Mechanisms of Autism. Recent Advances in Autism, 1-10.

Careaga, M., Van de Water, J., \& Ashwood, P. 2010. Immune Dysfunction in Autism: A Pathway to Treatment. Neurotherapeutics, 7(3), 283-292.

Center for Disease Control and Prevention (CDC). 2014. Community Report on Autism. United States: The Autism and Developmental Disabilites Monitoring Network.

Center for Disease Control and Prevention (CDC). 2016. Community Report on Autism. United States: The Autism and Developmental Disabilites Monitoring Network.

Chez M.G., Dowling T., Patel P.B., Khanna P., \& Kominsky M. 2007. Elevation of Tumor Necrosis Factor-alpha in Cerebrospinal Fluid of Autistic Children. Pediatr Neurol, 36: 361365.

Coondoo, Arijit. 2011. Cytokines in Dermatology A Basic Overview. Indian J Dermatol, 56 (4): 368-374.
Devlin B, \& Scherer SW. 2012. Genetic Architecture in Autism Spectrum Disorder. Curr Opin Genet Dev, 22: 229-237

Elamin, N. E., \& Al-ayadhi, L. Y. 2015. Genetic Markers Association in Autism Spectrum Disorder. Journal of Clinical \& Medical Genomics, 3(2): 1-5.

Enstrom AM, Van de Water JA, Ashwood P. 2009. Autoimmunity in autism. Curr Opin Investig Drugs, 10: 463473.

Feghali, C.\&Wright, T. M. 1997. Cytokines In Acute And Chronic Inflammation. Frontiers in Bioscience, 2: 12-26.

Gadient, R. A., \& Otten, U. 1994. Expression of interleukin-6 (IL-6) and interleukin-6 receptor (IL-6R) mRNAs in rat brain during postnatal development. Brain Res, 637(12):10-14.

Gilmore, J.H., Fredrik, J. L., Vadlamudi S, Lauder, J.M. 2004. Prenatal Infection and Risk for Schizophrenia: IL-1beta, IL-6, and TNFalpha Inhibit Cortical Neuron Dendrite Development. Neuropsychopharmacology, 29:1221-1229.

Gips, M. R., \& Srinivasan, P. 2012. Modeling Autism: a Systems Biology Approach. Journal of Clinical Bioinformatics, 2 (1): 1-15.

Gottfried, C., Junior, V. B., Francis , F., Riesgo, R., \& Savino, W. 2015. The Impact of Neuroimmune Alterations in Autism Spectrum Disorder. Front. Psychiatry, 6:121.

Gouwy M., Struyf S., Proost P., \& Van Damme J. 2005. Synergy in Cytokine and Chemokine Networks Amplifies the Inflammatory 
Response. Cytokine Growth Factor Rev, 16:561-580.

Hack, M., Taylor, H. G., Schluchter, M., Andreias, L., Drotar, D., \& Klein, N. 2009. Behavioral outcomes of extremely low birth weight children at age 8 years. Journal of Developmental and Behavioral Pediatrics, 30, 122-130.

Halter J., Steinberg J., \& Fink G. 2005. Evidence of Systemic Cytokine Release in Patients Undergoing Cardiopulmonary Bypass. J Extra Corpor Technol, 37: 272-277.

Hertz-Picciotto I, Green PG, Delwiche L, Hansen R, Walker C, Pessah IN. 2010. Blood Mercury Concentrations in Charge Study Children with and without Autism. Environ Health Perspect, 118(1): 161-166.

Huang, R. P. 2004. Cytokine protein arrays. Methods in Molecular Biology, 278, 215-232

Hwang, Y. S., Weng, S. F., Cho, C. Y., \& Tsai, W.H. (2013). Higher prevalence of autism in Taiwanese children born prematurely: A nationwide population-based study. Research in Developmental Disabilities, 34(9): 2462-2468.

Indredavik, M. S., Vik, T., Heyerdahl, S., Kulseng, S., Fayers, P., \& Brubakk, A. M. 2004. Psychiatric symptoms and disorders in adolescents with low birth weight. Archives of Disease in Childhood, 89, 445-450.

Jalal, E. A. 1998. Mast cell Konsep Baru Tentang Ciri Morfologik dan Fungsinya. Jurnal Kedokteran Yarsi, 6 (3): $28-40$.

Kementrian Kesehatan RI. 2015. Dedikasi untuk Anak Autis. Jakarta: Mediakom Edisi 60, Juli 2015.

Khan, M. M. 2008. Chapter 2 Role of
Cytokines. Immunopharmacology, DOI: 10.1007/978-0-387-77976-8 2. Springer Science+Business Media.

Lee, J. H., Espinera, A. R., Chen, D., Choi, K.-E., Caslin, A. Y., Won, S., ... Yu, S. P. 2016. Neonatal Inflammatory Pain and Systemic Inflammatory Responses as Possible Environmental Factors in the Development of Autism Spectrum Disorder of Juvenile Rats. Journal of Neuroinflammation, 13 (1): 109.

Li X., Chauhan A., Sheikh A.M., Patil S., Chauhan V., Li X.M., Ji L., Brown T., \& Malik M. 2009. Elevated immune response in the brain of autistic patients. J Neuroimmunol, 207:111-116.

Mokart D, Capo C, Blache JL. 2002. Early Postoperative Compensatory anti Inflammatory Response Syndrome is Associated with Septic Complications after Major Surgical Trauma in Patients with Cancer. $\mathrm{Br}$ J Surg, 89, 1450-1456.

Money J, Bobrow NA, Clarke FC. 1971. Autism and Autoimmune Disease: a Family Study. J Autism Child Schizophr, 1: 146-160.

Netea M.G., Van der Meer J.W., Van Deuren M. \& Kullberg B.J. 2003. Proinflammatory cytokines and sepsis syndrome: not enough, or too much of a good thing?. Trends Immunol, 2 24:254-258.

Onore, C., Careage, M., \& Ashwood, P. 2012. The Role of Immune Dysfunction in the Pathophysiology of Autism. Brain Behav Immun, 26 (3): 383-392.

Perkins N.D. NF-kappaB: Tumor Promoter or Suppressor? Trends Cell Biol, 14 (2): 64-69.

Repa, J. J., Li, H., Cannon, T.C.F., 
Valasek, M. A., Turley, S. D., Tansey, M. G., \& Dietschy, J. M. 2007. Liver $X$ Receptor Activation Enhances Cholesterol Loss from the Brain, Decreases Neuroinflammation, and Increases Survival of the NPC1 Mous. The Journal of Neuroscience, 27(52):14470 -14480.

Schmidt RJ, Hansen RL, Hartiala J, Allayee H, Schmidt LC, Tancredi DJ, Tassone F, Hertz-Picciotto I. 2011. Prenatal vitamins, one-carbon metabolism gene variants, and risk for autism. Epidemiology, 22(4): 476-485.

SchmidtRJ, TancrediDJ, OzonoffS, Hansen RL, Hartiala J, Allayee H, Schmidt LC, Tassone F, Hertz-Picciotto I. 2012. Maternal periconceptional folic acid intake and risk of autism spectrum disorders and developmental delay in the CHARGE (CHildhood Autism Risks from Genetics and Environment) case-control study. Am J Clin Nutr, 96 (1): 80-89.

Schmidt, O. I., Heyde C. E., Ertel, W. Stahel P. F. 2005. Closed head injury-an inflammatory disease? Brain Research Reviews, 48 (2005) 388-399.

Schottenfeld, D. \& Dimmer,J. 2006. Chronic Inflammation: A Common and Important Factor in the Pathogenesis of Neoplasia. Cancer J Clin, 56: 69-83.

Sealey, L.A.; Hughes, B.W.; Sriskanda, A.N.; Guest, J.R.; Gibson, A.D.; Johnson-Williams, L.; Pace, D.G.; Bagasra, O. 2008. Environmental factors in the development of autism spectrum disorders. Environ. Int. 88, 288-298

Sealey, L.A.; Hughes, B.W.; Sriskanda, A.N.; Guest, J.R.; Gibson, A.D.; Johnson-Williams, L.; Pace, D.G.; Bagasra, O. 2016. Environmental factors in the development of autism spectrum disorders. Environ. Int., 88, 288-298.

Stankov, S. V. 2012. Definition of Inflammation, Causes of Inflammation and Possible Antiinflammatory Strategies. The Open Inflammation Journal, 5, 1-9.

Theoharides TC, Alysandratos KD, Angelidou A, Delivanis DA, Sismanopoulos N, Zhang B, Asadi S, Vasiadi M, Weng Z, Miniati A, Kalogeromitros D. 2010. Mast cells and inflammation. Biochim Biophys Acta, 2010:21-33.

Theoharides, T. C., Asadi, S., \& Patel, A. B. 2013. Focal Brain Inflammation and Autism. Journal of Neuroinflammation, 2013, 10:46.

Tsilioni, I., Taliou, A., Francis, K., \& Theoharides, T.C. Children with Autism Spectrum Disorders, who Improved with A Luteolin Containing Dietary Formulation, Show Reduced Serum Levels of TNF and IL-6. Translational Psychiatry , $1-5$.

Vargas, D. L., Nascimbene, C., Krishnan, C., Zimmerman, A. W., \& Pardo, C. A. 2005. Neuroglial Activation andNeuroinflammation in the Brain of Patients with Autism. Annals of Neurology, 57 (1): 67-81.

Volk HE, Hertz-Picciotto I, Delwiche L, Lurmann F, McConnell R. 2011. Residential proximity to freeways and autism in the CHARGE study. Environ Health Perspect, 119 (6): 873-877.

Wang, Q. M., Luo, A. Z., \& Kong, X. 2014. Neuroinflamation and Autism. N A J Med Sci, 7(3):118-122.

Wassung, Keith. 2012. The Role Of Inflammation In The Healing 
Process. the field of health education and research.

Wei, H., Zou , H., Sheikh , A.M., Malik, M., Dobkin, C., Brown, W.T., \& Li, X. 2011 IL-6 is Increased in the Cerebellum of Autistic Brain and Alters Neural Cell Adhesion, Migration and Synaptic Formation. J Neuroinflamm, 8:52.

Wei, H., Alberts, I., \& Li, X. 2013. Review: Brain IL-6 and Autism. Neuroscience, (252): 320-325.

WHO (World Health Organization). 2013. Autism Spectrum Disorders \& Other Developmental Disorders From Raising Awareness to Building Capacity. Switzerland: WHO Press.

Wijngaarden E, V., Davidson PW, Smith TH, Evans K, Yost K, Love T, Thurston SW, Watson GE, Zareba G, Burns CM, Shamlaye CF, Myers
GJ. 2013. Autism Spectrum Disorder Phenotypes and Prenatal Exposure to Methylmercury. Epidemiology, 24(5): 651-659.

Streit, W. J., Mrak, R. E., \& Griffin, W. S. T. 2005. Microglia and Neuroinflamation: A Pathological Perspective. Journal of Neuroinflamation, 2004 (1-14).

Yirmiya, R., \& Goshen I .2011. Immune Modulation of Learning, Memory, Neural Plasticity and Neurogenesis. Brain Behav Immun, 25:181-213.

Young, A. M. H., Chakrabarti, B., Roberts, D., Lai, M., Suckling, J., \& Baron-Cohen, S. 2016. From Molecules to Neural Morphology: Understanding Neuroinflammation in Autism Spectrum Condition. Molecular Autism, 7 (9): 1-8. 